\title{
Ichthyoplankton interchange in the mouth region of a southern African estuary
}

\author{
A. K. Whitfield \\ J. L. B. Smith Institute of Ichthyology, Private Bag 1015, Grahamstown 6140, South Africa
}

\begin{abstract}
Migration patterns of ichthyoplankton in the seasonally open Swartvlei estuary were monitored during 1986/87 with particular emphasis on exchange between the estuary and sea. Four groups of fishes are recognised in the area according to breeding and recruitment strategies. Group 1 consists of species (e.g. Rhabdosargus holubi and Monodactylus falciformis) which spawn at sea, enter the estuary mainly as postlarvae, and congregate along the margins or on the bottom where water current speeds are reduced. Group 2 species (e.g. Spondyliosoma emarginatum and Etrumeus whiteheadi) also spawn at sea, their larvae are swept into the estuary on the flood tide, but are returned to the marine environment on the ebb tide. Breeding and larval development of Group 3 species (e.g. Hippocampus capensis and Syngnathus acus) occur within the estuary, although some eggs and larvae are lost to the sea following opening of the mouth. Group 4 larvae (e.g. Psammogobius knysnaensis and Caffrogobius spp.), which hatch from demersal eggs in the estuary, leave the system on the ebb tide before returning several weeks later as postlarvae. Diel ichthyoplankton density changes in the lower reaches of the Swartvlei estuary revealed that movements of larvae and postlarvae between the estuary and marine environment occurred mainly during twilight/nocturnal hours. The above data, together with a hydrodynamic model of the estuary, has enabled the quantification of ichthyoplankton exchange over specific 24 h periods.
\end{abstract}

\section{INTRODUCTION}

The interactions between hydrographic features of an estuary and fish population maintenance have received increasing attention from ichthyologists in recent years (Boehlert \& Mundy 1988). Interest has centred primarily upon the ability of estuarine spawned fish larvae to remain within these systems (Weinstein et al. 1980) and the strategies employed by marine ichthyoplankton recruiting into highly productive estuarine environments (Miller et al. 1984). Despite an increase in research effort, the general mechanisms by which fish larvae and postlarvae recruit to and concentrate in estuaries are poorly understood (Lawler et al. 1988).

The importance of recruitment processes in structuring estuarine fish assemblages is widely recognised, but research both in southern Africa and elsewhere has only recently gathered momentum (e.g. Fortier \& Leggett 1983, Pollock et al. 1983, Beckley 1985, Gascuel 1986, Roper 1986). The above authors have quantified ichthyoplankton immigration and emigration in terms of numbers per unit volume sampled, but no estimates of larval and postlarval fluxes were undertaken. Using the hydrodynamic model of Huizinga (1987), together with ichthyoplankton density information, an attempt has been made to calculate the flux of individual species into and out of the Swartvlei estuary over specific $24 \mathrm{~h}$ periods. In addition, this study represents the first detailed account of larval and postlarval movements in a shallow ( 1 to $3 \mathrm{~m}$ ) seasonally open estuary, and identifies a new recruitment strategy by estuarine Gobiidae and Blenniidae.

\section{STUDY AREA}

The Swartvlei estuary $\left(34^{\circ} 01^{\prime} \mathrm{S}, 22^{\circ} 46^{\prime} \mathrm{E}\right)$ is situated in the southern Cape (South Africa) and comprises a $7.2 \mathrm{~km}$ sinuous channel linking a coastal lake to the sea (Fig. 1). The estuary is very shallow (maximum depth $=$ $4 \mathrm{~m}$ ) with a narrow central channel bordered by intertidal sand flats (Kluger 1975). The sediments of the entire estuary consist of recently deposited dune sands, with the exception of the mouth area where dune rock borders the eastern shore. The mouth of the estuary is normally closed during winter and open in summer (Whitfield et al. 1983). 


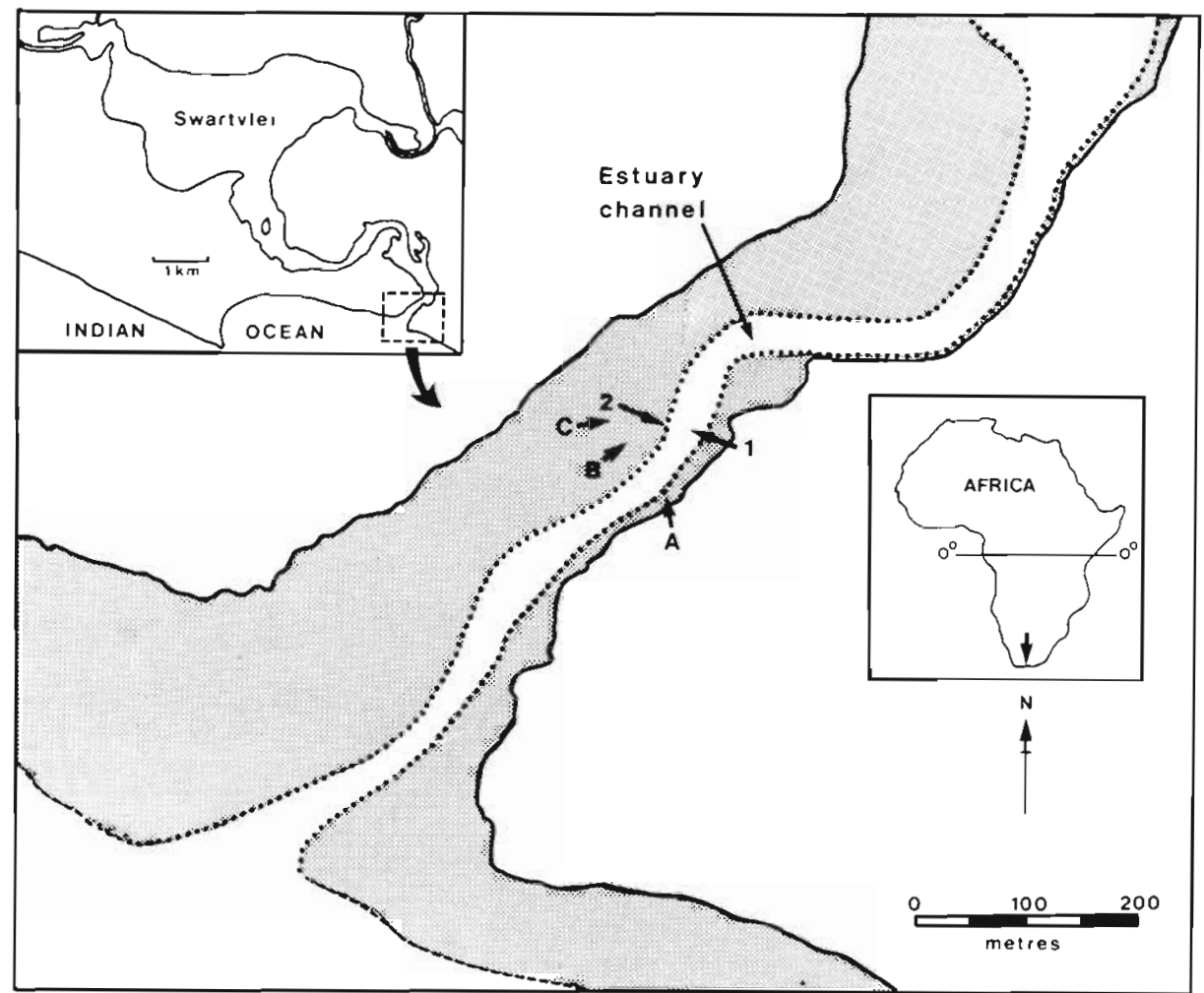

Fig. 1 The Swartvlei estuary. South Africa, showing the channel (1) and channel margin (2) sampling stations. Positions of water current speed transects $A-B$ and A-C are also shown. Stippled areas indicate exposed sand at low tide
Salinity decreases up the system (Whitfield 1988a) and from spring to neap tides (Liptrot 1978). During a tidal cycle a substantial volume of water is retained within the estuary, which means that over a period of several tides the water in the middle section of the estuary moves back and forth with the seawater front acting as a piston. Because incoming tides enter more rapidly than outgoing tides exit, the estuary tends to fill with water (maximum $=1.3 \mathrm{~m}$ above MSL) dunng the days approaching spring tide, whilst the reverse occurs during neap tides (Kluger 1975). Thus the lowest water levels (ca $0.3 \mathrm{~m}$ above MSL) occur during the neap tudal cycle. Water current velocitres in the mouth region can attain $1.5 \mathrm{~m} \mathrm{~s}^{-1}$ durng spring flood tides.

Salinities above $30 \%$ occur throughout the estuary immediately prior to and after mouth closure. Salinity then declines during the closed phase as water from Swartvlel is displaced by the ruvers into the estuary. and the water level of the system nses. Minumum salınities $(<5 \%)$, which are of short duration $(<10 \mathrm{~d})$, occur when the mouth has opened following a prolonged closed phase and the rivers are flooding. Temperature in the estuary ranges from 10 to $20^{\circ} \mathrm{C}$ in shallow areas, and from 15 to $27^{\circ} \mathrm{C}$ in channel surface waters

The Swartvlel estuary has well-developed Zostera capensis and Ruppla cirrhosa plant beds, whereas the lake littoral zone is dominated by the submerged macrophyte Potamogeton pectinatus and Charophyta. The juvenile and adult fish fauna associated with these aquatic plant beds has been described by Kok \& Whitfield (1986) and Whitfield (1984, 1986, 1988b).

\section{MATERIALS AND METHODS}

In this study the word larva designates that stage in the life history from hatching to attainment of complete fin ray counts and beginning of squamation, at which stage the fish becomes a juvenile (Kendall et al. 1984). Ichthyoplankton includes both larval forms and the transitional stage between larva and juvenile, which is called the metamorphic larva (Melville-Smith 1978) or postlarva.

Plankton samples in the mouth region of the Swartvlei estuary (Fig.1) were collected during five $24 \mathrm{~h}$ sessions between March 1986 and January 1987. Two sessions in October gave similar results and therefore only one of these is analysed in detail. Channel collections (Stn 1) were made with a $75 \mathrm{~cm}$ diameter WP2 plankton net (500 um St Martin's nylon mesh) fitted with a calibrated Kahlsico digital flow meter (No. 005WB138) In addition, during October 1986 surface and bottom samples were collected with a $57 \mathrm{~cm}$ diameter WP2 plankton net. The net was attached to a rotating boom on the bow of a $4 \mathrm{~m}$ boat such that both surface and bottom samples could be collected from undisturbed waters $>0.5 \mathrm{~m}$ from the side. Samples $(20$ 
to $40 \mathrm{~m}^{3}$ ) were collected whilst the boat was moored and current speeds exceeded ca $0.7 \mathrm{~m} \mathrm{~s}^{-1}$. When water current velocities declined below $0.7 \mathrm{~m} \mathrm{~s}^{-1}$ the boat, powered by an outboard motor, was directed against the current. Plankton was preserved at the sampling site with buffered formaldehyde to give a total formalin concentration of ca $5 \%$.

During each 24 h sampling session the following surface and bottom physico-chemical measurements were made in the channel prior to ichthyoplankton collection. Water temperature was determined using a thermometer $\left( \pm 0.1 \mathrm{C}^{\circ}\right)$, salinity with an $\mathrm{AO}$ Instruments refractometer $( \pm 1 \%$ ) and water current using an NBA. direct reading current meter. Data on tidal height were obtained from a gauge plate at the site of collection as well as an Ott tide level recorder situated $1 \mathrm{~km}$ from the estuary mouth.

Estimates of water current speeds across a section of the estuary, adjacent to the ichthyoplankton sampling site (Fig. 1), were determined using the NBA current meter which was attached to a calibrated winch on board the boat. The 2 ends of a rope, which was suspended parallel to the water surface, were attached to poles at positions $\mathrm{A}$ and $\mathrm{C}$. Water current velocities during a spring tidal cycle were measured at ca $30 \mathrm{~cm}$ depth intervals, every $5 \mathrm{~m}$ along the rope. Current speeds recorded at the peak of the ebb and flood tide are shown in Fig. 2.

A rectangular $(1.0 \times 0.6 \mathrm{~m})$ push net $(500 \mu \mathrm{m}$ nylon mesh) fitted with a calibrated Kahlsico flow meter (No. 005WA130) was used to capture fish larvae and $0+$ juveniles along the edges of the estuary channel (Stn 2). The net was pushed parallel to the shore such that the mouth of the net was directed into the prevailing water current, which was generally weak or absent (Fig. 2). Each sample, filtered from 20 to $40 \mathrm{~m}^{3}$ of water, was preserved in formalin at the site of collection.
In the laboratory, fish larvae were separated from the rest of the plankton using a stereo-microscope. All larvae and juveniles were then identified to the lowest possible taxon, measured (standard length) to the nearest $0.1 \mathrm{~mm}$ using an ocular micrometer or vernier calipers, and their numbers expressed per $10 \mathrm{~m}^{3}$ of water filtered. Shrinkage of specimens during preservation was not corrected for in this study, but all measurements were conducted within $30 \mathrm{~d}$ of collection.

A 1-dimensional hydrodynamic model developed by the South African National Research Institute of Oceanology (Huizinga 1987), together with fish densities from specific $24 \mathrm{~h}$ periods, was used to compute the exchange of ichthyoplankton in the mouth region of the Swartvlei estuary. Inflow and outflow of water $\left(\mathrm{m}^{3}\right)$ across the collection site was calculated on an hourly basis and matched with ichthyoplankton densities recorded in that particular hour. The total number of fish larvae and postlarvae of a particular species moving into or out of the estuary per hour was then estimated by multiplying the density $\mathrm{m}^{-3}$ by the volume of water $\left(\mathrm{m}^{3}\right)$ entering or leaving the estuary during that hour. Numbers were then summed for flood and ebb tides to determine exchange during each $24 \mathrm{~h}$ period

\section{RESULTS}

\section{Session 1 (22 to 23 October 1986)}

This $24 \mathrm{~h}$ sampling session was conducted $8 \mathrm{~d}$ after the opening of the estuary mouth and $5 \mathrm{~d}$ after spring tide. Peak ebb and flood flow rates across the section were ca $32 \mathrm{~m}^{3} \mathrm{~s}^{-1}$, but owing to the longer ebb period the total outflow over the tidal cycle $\left(1264000 \mathrm{~m}^{3}\right)$ was considerably higher than the total inflow $\left(588000 \mathrm{~m}^{3}\right)$

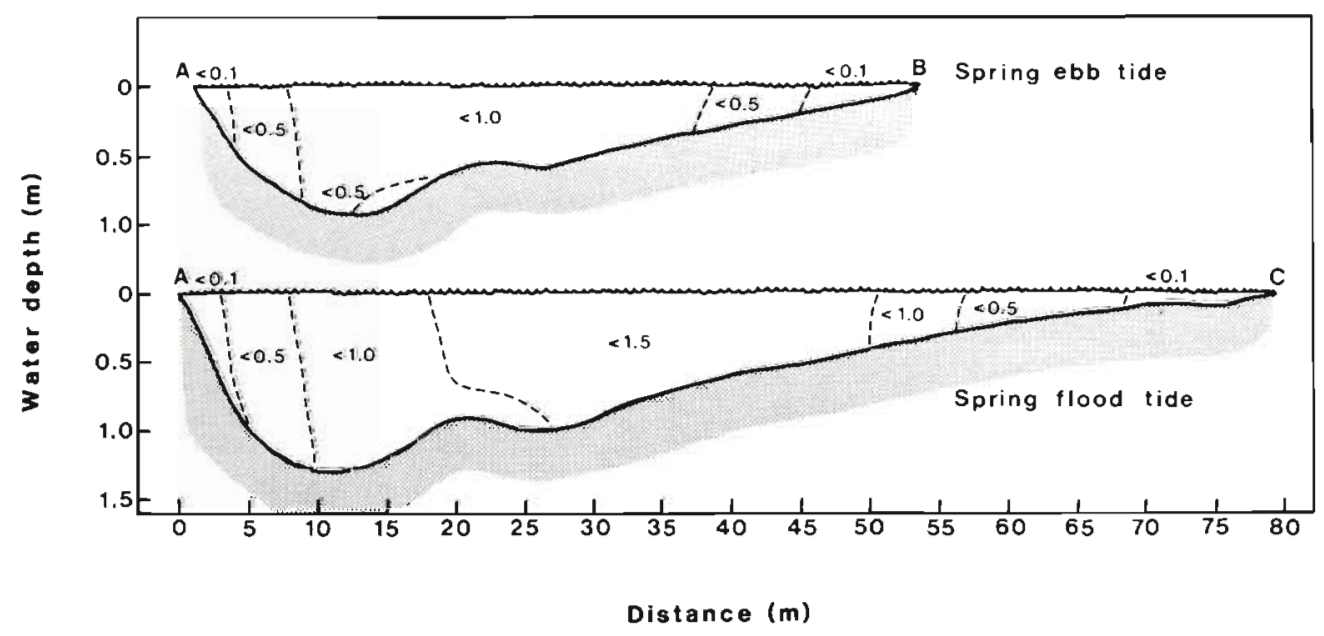

Fig. 2. Peak water current speeds $\left(\mathrm{m} \mathrm{s}^{-1}\right)$ recorded during a spring ebb and flood tide respectively. Localities of transects A-B and A. - C are shown in Fig. 1 


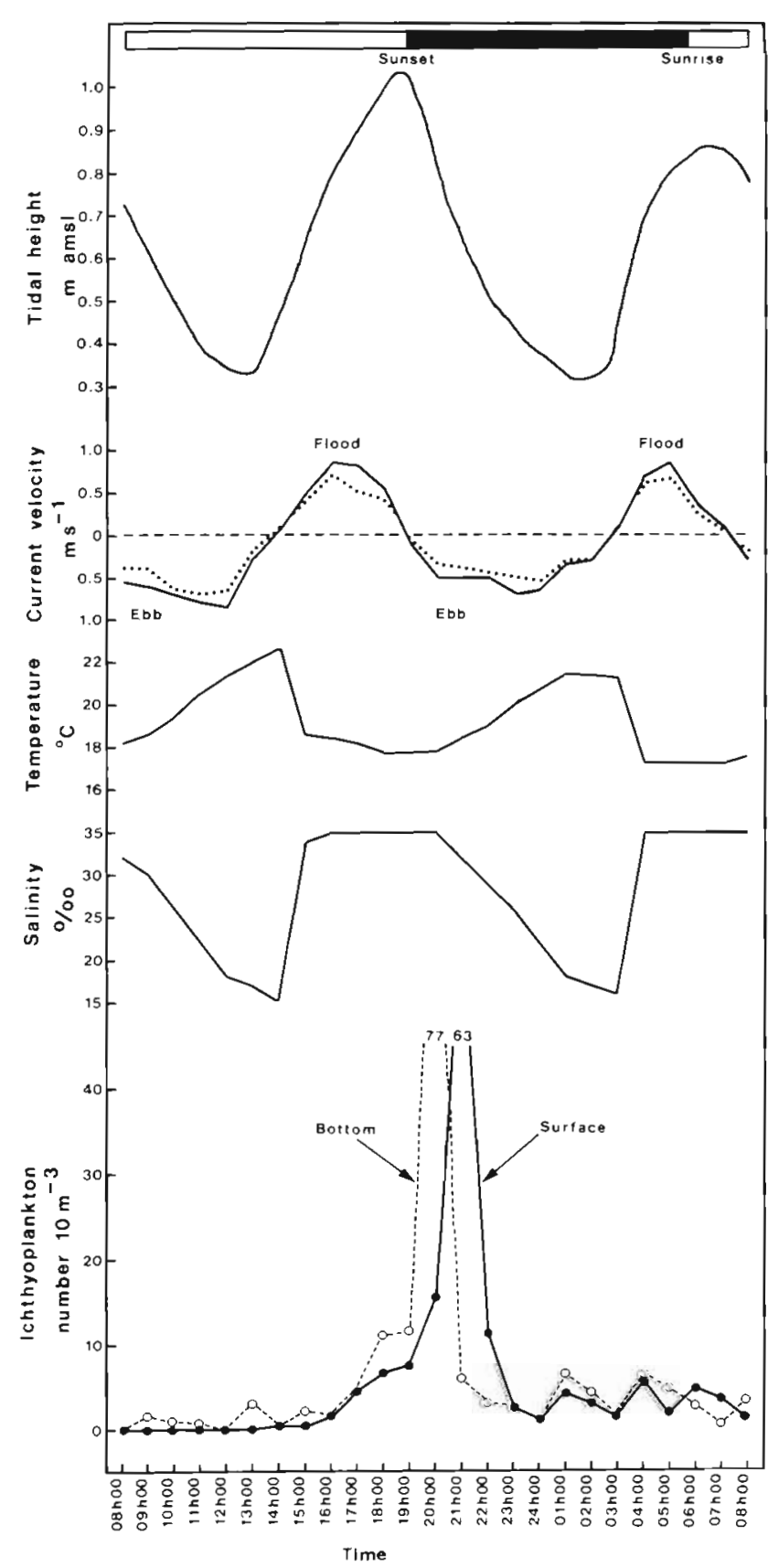

Fig. 3. Changes in ichthyoplankton abundance and physical parameters during a $24 \mathrm{~h}$ sampling session (22 to 23 Oct 1986) in the Swartvlei estuary mouth region. Bottom values differing from surface measurements are indicated by dotted lines

(Huizinga 1987). The tidal range was $0.7 \mathrm{~m}$ and mean surface water velocities attained $0.9 \mathrm{~m} \mathrm{~s}^{-1}$ on both flood and ebb tides (Fig. 3). Water temperatures exceeded $20^{\circ} \mathrm{C}$ on the ebb tide but declined below $18^{\circ} \mathrm{C}$ on the flood tide. In contrast salinities declined to $15 \%$ on the ebb tide before increasing to $35 \%$ on the flood tide (Fig. 3).

Ichthyoplankton densities were low during most of the sampling period (Fig. 3). Between 15:00 and 18:00 h larval Spondyliosoma emarginatum ( 3 to $5 \mathrm{~mm}$ SL) were recorded entering the estuary in increasing numbers but were lost in almost equal quantities on the following ebb tide (Fig. 4). This contrasted to the emigration (19:00 to 21:00 h) of large numbers (>100000) of Caffrogobius ?multifasciatus larvae (2 to $4 \mathrm{~mm} \mathrm{SL}$ ) which were not recorded returning to estuary until the postlarval stage had been attained. Other important species moving out of the estuary on the nocturnal ebb tide included Syngnathus acus (10 to $15 \mathrm{~mm} \mathrm{SL})$ and Psammogobius knysnaensis (2 to $3 \mathrm{~mm}$ SL). Some immigration of marine postlarvae (Group 1) was also measured (Table 1), despite the fact that the estuary had been open for only $8 \mathrm{~d}$.

Larval densities in surface and bottom waters followed the same pattern (Fig. 3) and were found to be not significantly different (Wilcoxon matched-pairs signed-ranks test). Ichthyoplankton densities were, however, significantly higher (Mann-Whitney $U$-test,

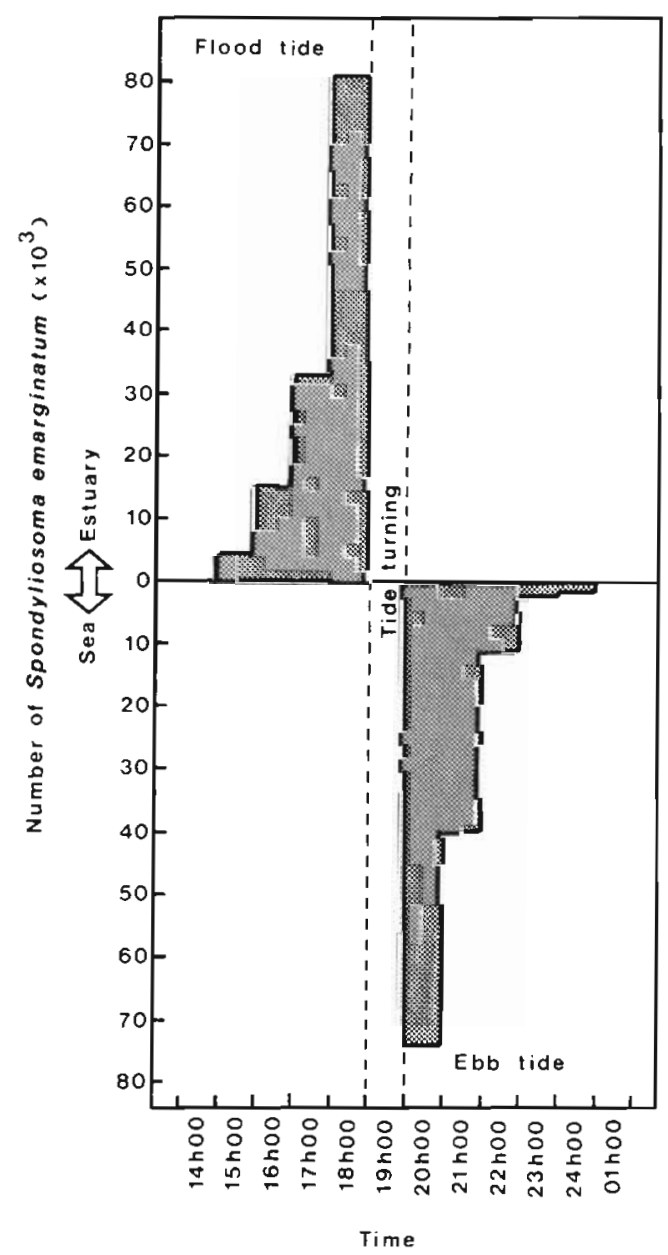

Fig. 4. Spondyliosoma emarginatum. Numbers of larvae moving into and out of the estuary over a $12 \mathrm{~h}$ period (22 to $23 \mathrm{Oct}$ 1986) 
Table 1 Net gain or loss of abundant ichthyoplankton moving into (+) and out of $(-)$ the Swartvlei estuary mouth over $24 \mathrm{~h}$ periods. Numbers are calculated from the actual densities (ind $\mathrm{m}^{-3}$ ) for each species, in conjunction with the estimated volumes $\left(\mathrm{m}^{3}\right)$ of water entering and leaving the estuary (see 'Materials and methods' for details)

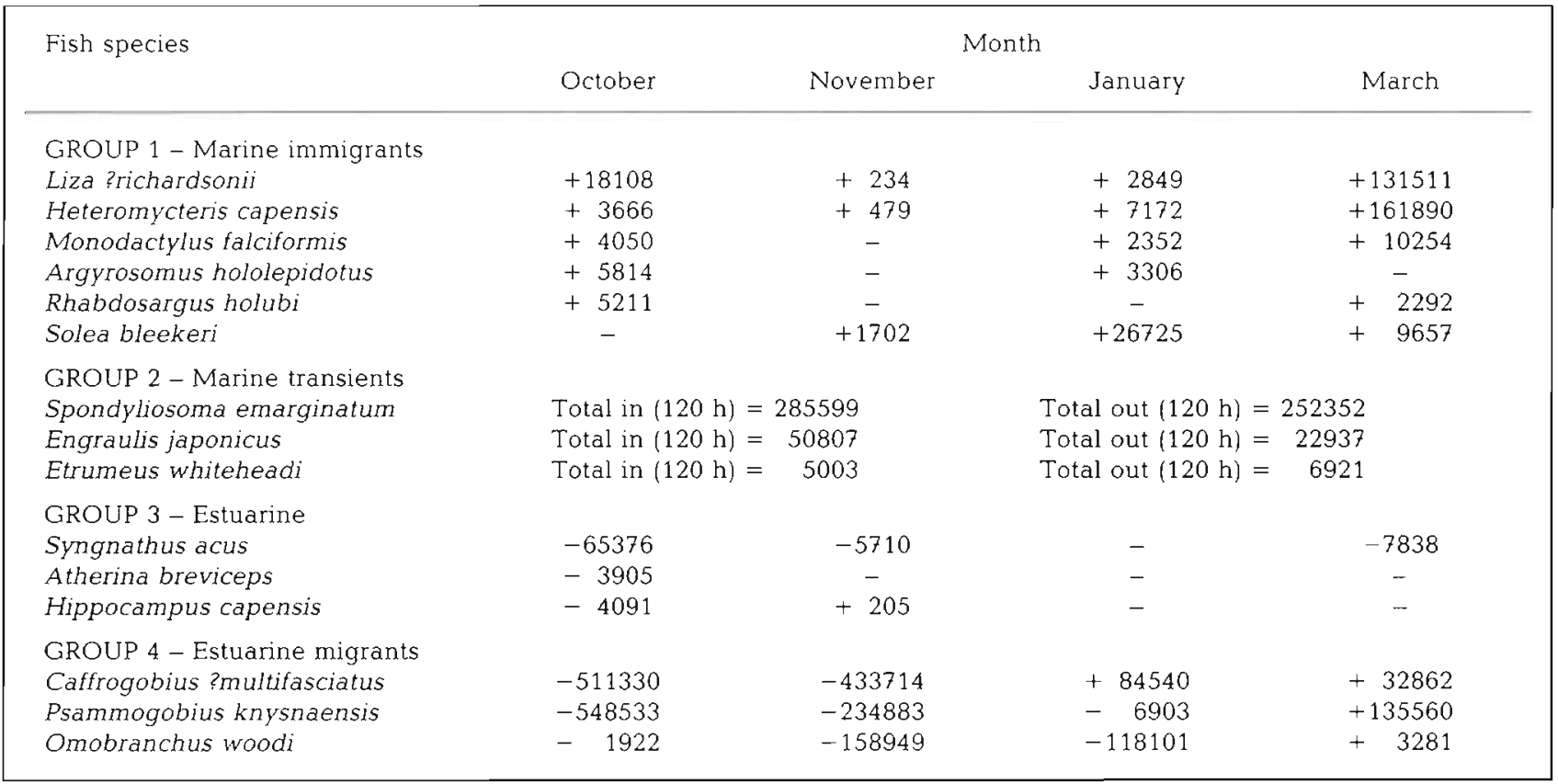

$p<0.01)$ at night $\left(\overline{\mathrm{x}}=9\right.$ ind. $\left.10 \mathrm{~m}^{-3}\right)$ than during the day $\left(\overline{\mathrm{x}}=2\right.$ ind. $\left.10 \mathrm{~m}^{-3}\right)$.

A 24 h sampling session from 29 to 30 October 1986 gave similar results to the above, and is therefore not analysed in detail. Caffrogobius ?multifasciatus (2 to $4 \mathrm{~mm} \mathrm{SL}$ ) and Syngnathus acus (11 to $15 \mathrm{~mm} \mathrm{SL}$ ) larvae were washed out of the estuary on the nocturnal ebb tide and large numbers $(>100000)$ of Psammogobius knysnaensis larvae ( 2 to $3 \mathrm{~mm} \mathrm{SL}$ ) were recorded leaving the estuary on both the diurnal and nocturnal ebb tides. In contrast to the previous sampling session (22 to $23 \mathrm{Oct}$ ) the sparid Spondyliosoma emarginatum was a minor component of the ichthyoplankton. No significant difference (Wilcoxon matched-pairs signed-rank test) was found between ichthyoplankton densities in surface and bottom waters.

\section{Session 2 (25 to 26 November 1986)}

This 24 h sampling session coincided with a neap tide, and tidal ranges were therefore considerably reduced (Fig. 5). Peak flow rates during flood were ca $18 \mathrm{~m}^{3} \mathrm{~s}^{-1}$ and during ebb $13 \mathrm{~m}^{3} \mathrm{~s}^{-1}$. Total estuarine inflow and outflow was estimated at 385000 and $528000 \mathrm{~m}^{3}$ respectively (Huizinga 1987). Water temperatures exceeded $23^{\circ} \mathrm{C}$ on the ebb tide but declined to $18^{\circ} \mathrm{C}$ on the flood tide. Salinities ranged between 22 and $35 \%$, with the lowest value recorded at the end of the ebb tide (Fig. 5).
The emigration of large numbers $(>150000$ for each species) of Omobranchus woodi (2 to $4 \mathrm{~mm} \mathrm{SL}$ ), Caffrogobius ?multifasciatus (2 to $4 \mathrm{~mm} \mathrm{SL}$ ) and Psammogobius knysnaensis ( 2 to $3 \mathrm{~mm}$ SL) larvae on the nocturnal ebb tide was a major feature of this sampling session (Table 1, Fig.5). An estimated 99000 Spondyliosoma emarginatum larvae (2 to $4 \mathrm{~mm}$ SL) entered the estuary between 21:00 and 24:00 h but 109000 were calculated leaving the estuary between 01:00 and 05:00 h. Overall channel ichthyoplankton densities were significantly higher (MannWhitney $U$-test, $p<0.01$ ) at night when compared with the day.

Very few marine postlarvae entered the estuary over this $24 \mathrm{~h}$ period (Table 1) but evidence of previous recruitment was recorded in push net catches along the margins of the channel. Shoals of Liza richardsonii 15 to $25 \mathrm{~mm}$ SL were captured in the shallows throughout the sampling session. Numbers were particularly high $\left(>100\right.$ ind $10 \mathrm{~m}^{-3}$ ) during the diurnal ebb tide, reaching a peak of 627 ind. $10 \mathrm{~m}^{-3}$ between 16:00 and 17:00 h. During the nocturnal ebb tide $L$. richardsonii densities ranged between 10 and 30 ind. $10 \mathrm{~m}^{-3}$. In contrast to the channel results, overall fish densities along the margins were significantly higher ( $t$-test for independent sample means, $p<0.02$ ) during the diurnal ebb tide when compared with the nocturnal ebb tide. This was due primarily to the large shoals of $0+$ juvenile $L$. richardsonii feeding in the shallows during the day. 


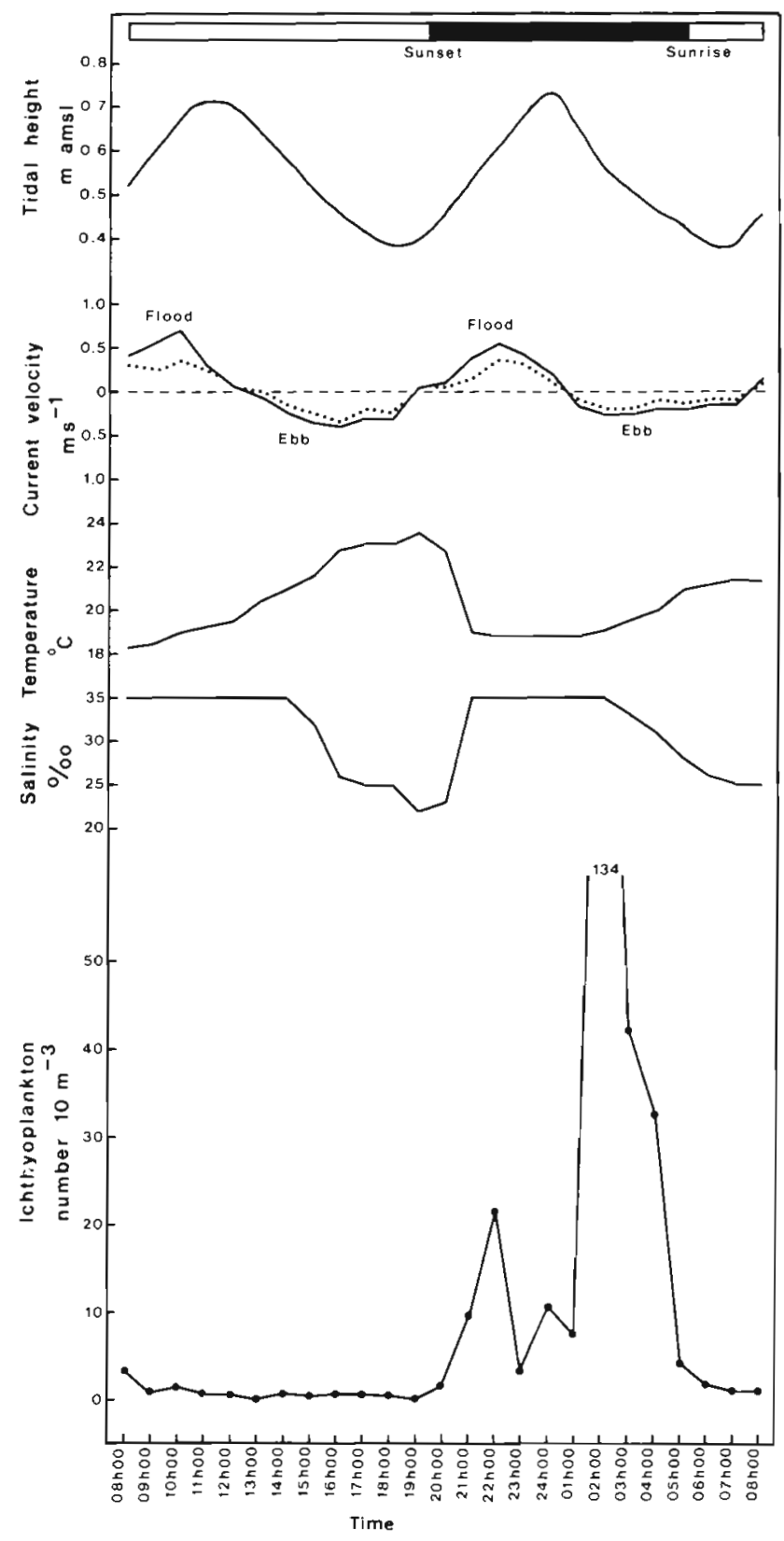

Fig. 5. Changes in ichthyoplankton abundance and physical parameters during a $24 \mathrm{~h}$ sampling session (25 to 26 Nov 1986 ) in the Swartvlei estuary mouth region. Bottom values differing from surface measurements are indicated by dotted lines

\section{Session 3 (15 to 16 January 1987)}

This sampling session coincided with a spring tide, but in contrast to Session 1 the tidal range was ca $0.5 \mathrm{~m}$ (Fig. 6) due to the development of a sand sill in the mouth. Peak inflow rates were ca 30 and $28 \mathrm{~m}^{3} \mathrm{~s}^{-1}$ for the 2 flood tides, while the equivalent values for the respective ebb tides were 24 and $22 \mathrm{~m}^{3} \mathrm{~s}^{-1}$ (Huizinga 1987). Total inflow volumes were $446000 \mathrm{~m}^{3}$ for the first flood tide and $315000 \mathrm{~m}^{3}$ for the second. Total

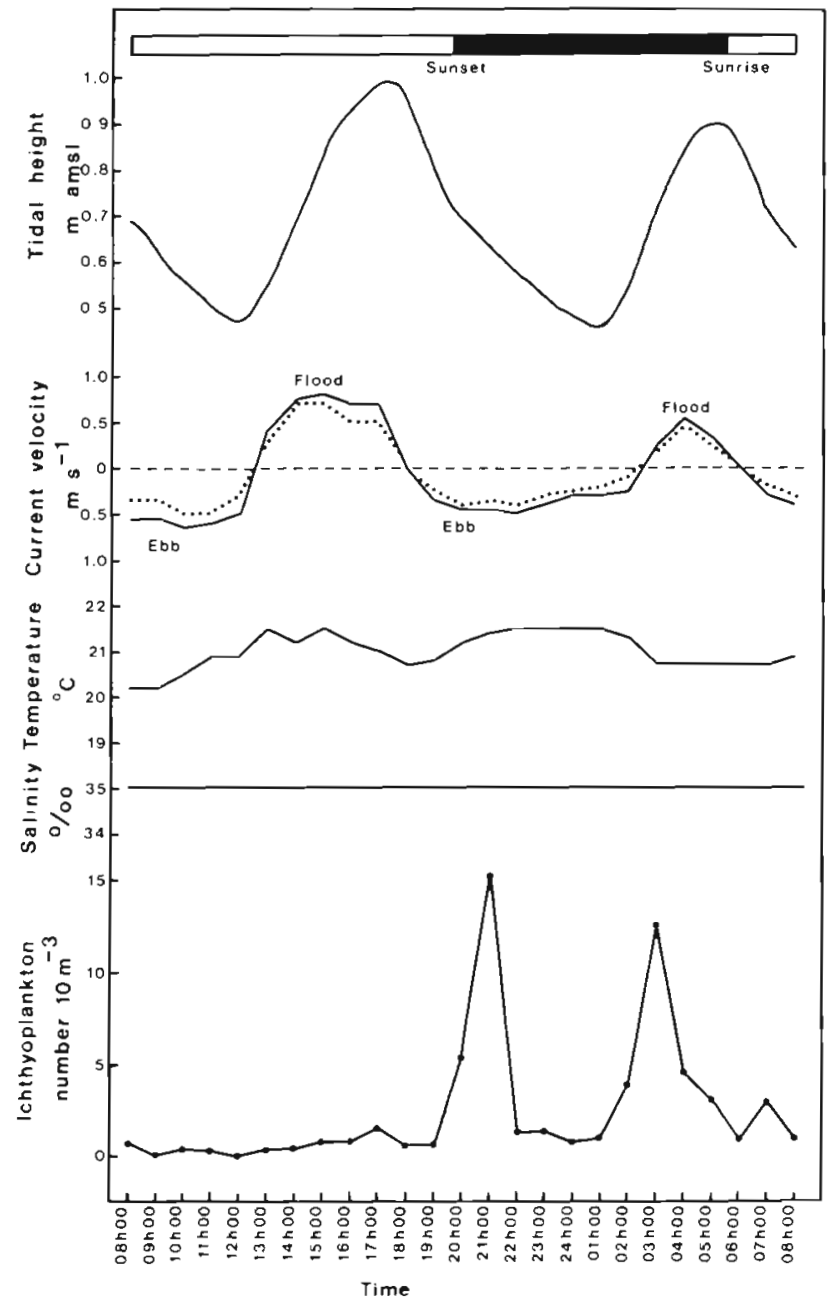

Fig. 6. Changes in ichthyoplankton abundance and physical parameters during a $24 \mathrm{~h}$ sampling session (15 to $16 \mathrm{Jan} 1987$ ) in the Swartvlei estuary mouth region. Bottom values differing from surface measurements are indicated by dotted lines

outflow volume for the $24 \mathrm{~h}$ period was estimated at $773000 \mathrm{~m}^{3}$. Water temperatures and salinities showed little or no variation during this sampling session (Fig. 6).

Movements of fish larvae and postlarvae into or out of the estuary occurred mainly at night (Fig. 6). Ichthyoplankton emigration declined to $<15$ ind. $10 \mathrm{~m}^{-3}$ and comprised mainly Omobranchus woodi and Psammogobius knysnaensis (Table 1). Immigration was dominated by the metamorphic larvae of Caffrogobius multifasciatus ( 8 to $10 \mathrm{~mm} \mathrm{SL}$ ) and marine species such as Solea bleekeri (4 to $5 \mathrm{~mm}$ SL), Heteromycteris capensis ( 6 to $8 \mathrm{~mm} \mathrm{SL}$ ), Monodactylus falciformis (5 to $6 \mathrm{~mm}$ ) and Liza richardsonii (9 to $11 \mathrm{~mm} \mathrm{SL}$ ) (Table 1). In contrast to the previous sampling session (25 to 26 Nov 1986) densities of $0+$ juvenile L. richardsonii along the channel margin were low $\left(\overline{\mathrm{x}}=1.4\right.$ ind $10 \mathrm{~m}^{-3}$, $\mathrm{SD} \pm 1.8)$. 


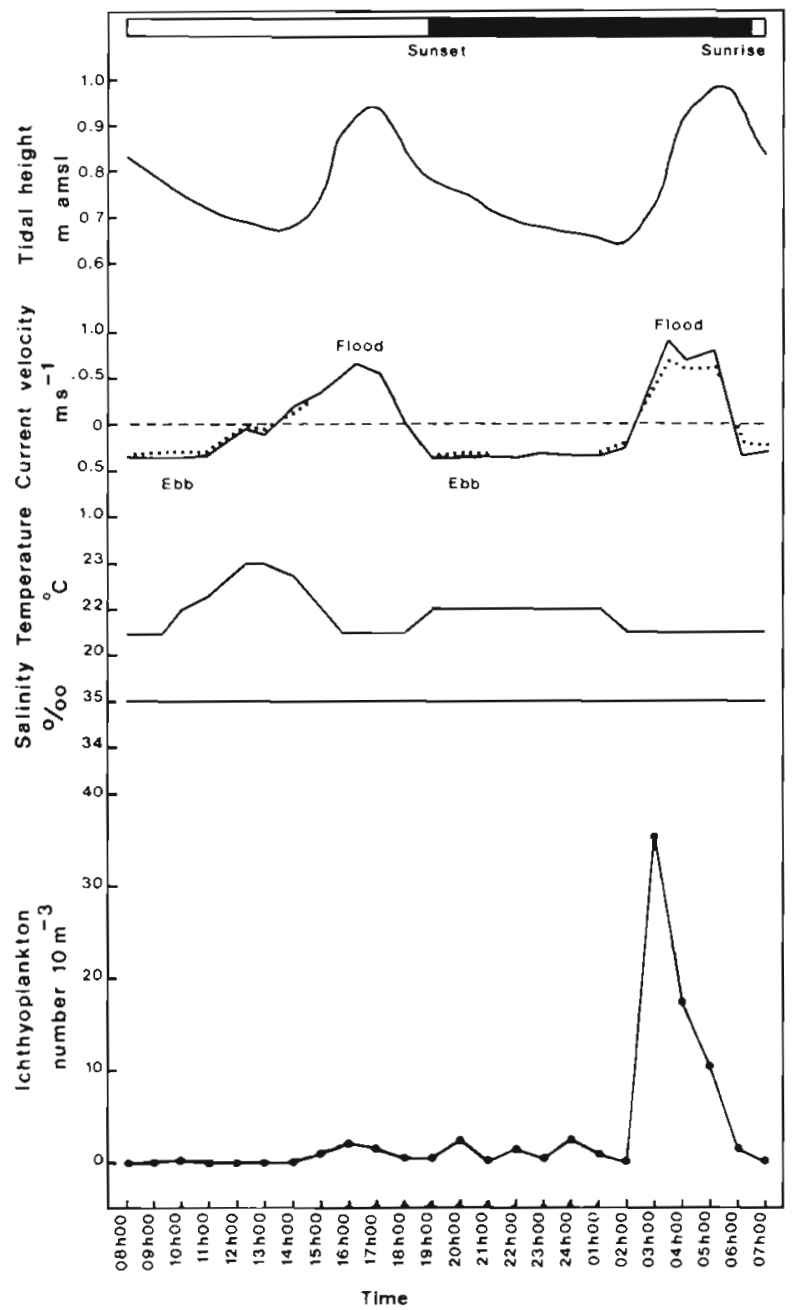

Fig. 7. Changes in ichthyoplankton abundance and physical parameters during a $24 \mathrm{~h}$ sampling session (11 to 12 Mar $1986)$ in the Swartvlei estuary mouth region. Bottom values differing from surface measurements are indicated by dotted lines

\section{Session 4 (11 to 12 March 1986)}

This session was conducted during a spring tide $20 \mathrm{~d}$ before the mouth closed. The sand sill in the mouth region was well developed and tidal amplitude considerably reduced (Fig. 7). The peak flood tide flow rate was $32 \mathrm{~m}^{3} \mathrm{~s}^{-1}$ and for the ebb was $18 \mathrm{~m}^{3} \mathrm{~s}^{-1}$ (Huizinga 1987). The duration of flood tides was only $4 \mathrm{~h}$ compared to ebb tides of $8 \mathrm{~h}$. This resulted in a total estimated inflow of $524000 \mathrm{~m}^{3}$ and outflow of $688000 \mathrm{~m}^{3}$. Surface and bottom salinities were constant $(35 \%)$ and water temperatures ranged between 21 and $23^{\circ} \mathrm{C}$.

No major emigration of ichthyoplankton was recorded during this sampling session (Table 1) but immigration of both estuarine (e.g. Psammogobius knysnaensis 6 to $7 \mathrm{~mm} \mathrm{SL}$, Caffrogobius multifasciatus
8 to $10 \mathrm{~mm} \mathrm{SL}$ ) and marine species (e.g. Heteromycteris capensis 6 to $8 \mathrm{~mm} \mathrm{SL}$, Liza ?richardsonii 8 to $10 \mathrm{~mm} \mathrm{SL}$, Rhabdosargus holubi 9 to $10 \mathrm{~mm}$ SL, Monodactylus falciformis 4 to $7 \mathrm{~mm} \mathrm{SL}$ ) occurred on the nocturnal flood tide. Recruitment during this tide rather than the corresponding diurnal flood tide (Fig. 7) suggests a positive nocturnal migratory response.

Push net sampling in the shallows also revealed a peak $\left(40.8\right.$ ind $\left.10 \mathrm{~m}^{-3}\right)$ in ichthyoplankton (e.g. Psammogobius knysnaensis 6 to $7 \mathrm{~mm} \mathrm{SL}$, Monodactylus falciformis 4 to $5 \mathrm{~mm} \mathrm{SL}$. Caffrogobius multifasciatus 8 to $10 \mathrm{~mm} \mathrm{SL}$, Heteromycteris capensis 7 to $8 \mathrm{~mm} \mathrm{SL}$, Liza ?richardsonii 8 to $10 \mathrm{~mm} \mathrm{SL}$ ) abundance between 03:00 and 04:00 h. Shoals of $0+$ juvenile L. richardsoni 15 to $40 \mathrm{~mm}$ SL were present along the channel margin throughout the session, and did not appear to migrate up the estuary on the flood tide.

\section{DISCUSSION}

Spawning by most estuarine-associated fishes in southern Africa occurs at sea (Wallace 1975) with the larvae and postlarvae leaving the marine environment to enter estuarine nursery areas (Whitfield 1983, Wallace et al. 1984). Factors influencing the recruitment of early life stages of these fishes into estuaries are multiple (Blaber \& Blaber 1980, Whitfield 1980) and, based on existing information, difficult to rank. A classification of fish species into groups using larval and postlarval recruitment strategies is however possible. Beckley (1985) identified 3 categories in the Swartkops estuary: (1) Marine species which spawn at sea but utilize the estuary as a nursery area. Larvae and juveniles enter on the flood tide.

(2) Incidental marine species which are spawned at sea and are likely to have an irregular estuarine influx and efflux of larvae.

(3) Resident estuarine species which spawn in the estuary and whose larvae occur regularly in the plankton. A proportion of these larvae may be lost from the estuary on the ebb tide as estuarine water flows seaward.

A fourth category can now be added to the above:

(4) Resident estuarine species spawning in the estuary, with most of the larvae leaving the system on the ebb tide and returning at the metamorphic or postlarval stage.

Examples of species from each of the above groups are given in Table 1 which illustrates the magnitude of ichthyoplankton movements in a shallow, well-mixed estuary.

Much research has been conducted in 2-layered estuaries (Weinstein et al. 1980, Fortier \& Leggett 1983, Henderson 1987) where it has been shown that larval 
recruitment and retention is often based upon the differences in direction of the net non-tidal flow between surface and bottom waters. This tactic would be of little use in a shallow, non-stratified estuary such as Swartvlei. Larvae and postlarvae of Group 1 species such as Liza richardsonii, Rhabdosargus holubi and Monodactylus falciformis recruiting into the Swartvlei estuary were swept up the system on the flood tide, before moving into shallow littoral areas to avoid the following ebb tide. In contrast, Group 2 species such as Spondyliosoma emarginatum, Etrumeus whiteheadi and Engraulis japonicus appeared to move passively up the estuary on the flood tide, only to be washed back into the marine environment on the ebb tide.

Eggs and larvae of Group 3 species such as Gilchristella aestuaria were recorded being washed out to sea by flood waters on 15 October 1986, $1 \mathrm{~d}$ after the estuary mouth had been opened. However $G$. aestuaria larvae were not recorded in any of the subsequent $24 \mathrm{~h}$ sessions, despite the fact that early life stages of this species were concurrently abundant in the lake-like upper reaches of the system (Whitfield 1989). A possible explanation could be that $G$. aestuaria spawn predominantly in the upper reaches of estuaries which are open (Melville-Smith \& Baird 1980, Talbot 1982) and also avoid being swept out to sea by virtue of their vertical distribution in the water column when tidal currents are present (Melville-Smith et al. 1981). Other Group 3 species (e.g. Hippocampus capensis and Syngnathus acus) breed in the lower reaches of the Swartvlei estuary, so the loss of a proportion of their postlarvae to the marine environment (Table 1) is to be expected.

Several authors have recorded large numbers of goby and blenny larvae leaving an estuary, similar to the pattern occurring with Group 4 species in the Swartvlei system (Table 1). Emigration by early blenny larvae has been documented by Beckley (1985) who found marked effluxes of Omobranchus woodi larvae on ebb tides. She did not record subsequent return migrations of the postlarvae of this species into the Swartkops estuary (S. Africa), possibly due to the short duration of the study. Beckley (1985) also found high densities of Caffrogobius multifasciatus and Psammogobius knysnaensis larvae leaving the Swartkops estuary on the ebb tide. Zedler \& Nordby (1986) determined that $61 \%$ of Tijuana estuary (California, USA) channel ichthyoplankton comprised 3 indistinguishable goby larvae, and speculated that the transportation of these larvae to the nearshore marine environment was fatal. Roper (1986) also found unidentified goby larvae being washed out of Whangateau Harbour estuary (New Zealand) where they were spawned, while older larvae of the same species recruited back into the estuary. Not all goby larvae follow the above pattern. Shenker et al. (1983) have described the move- ment of naked goby Gobiosoma bosci larvae up the Patuxent River estuary (Maryland, USA) and Massmann et al. (1963) have documented a similar upstream distribution pattern of $G$. bosci larvae in the York River estuary (Virginia, USA). It would appear that larval recruitment strategies employed by estuarine Gobiidae are diverse, and further research is required to ascertain why certain species utilize the sea and others the riverine environment as primary nursery areas.

Nocturnal migration patterns of estuarine larvae and postlarvae recorded in the Swartvlei estuary have also been documented by other authors (e.g. Eldridge 1977 , Boehlert \& Mundy 1987). Because of the shallowness of the Swartvlei estuary and absence of any layering, vertical migration by ichthyoplankton at night, as was recorded in the Cape Fear River estuary (N. Carolina, USA) (Weinstein et al. 1980), was unlikely to be responsible for diel density differences. Shoals of metamorphic mugilid and sparid larvae were observed maintaining their position in surface waters of both the Swartvlei estuary mouth and shallow regions of the surf zone during the day. At night these larvae would lose visual contact with fixed benthic reference points and tend to be transported by prevailing water currents, especially the stronger flood tides. This loss of rheotaxis may account for the increased migration of marine postlarvae into the estuary on nocturnal rather than diurnal flood tides. It does not, however, explain the emigration pattern of early goby and blenny larvae which are passively transported during twilight/nocturnal ebb tides. Although the influence of net avoidance (Fore \& Baxter 1972) on these results was not determined, the ability of larvae $<4 \mathrm{~mm}$ SL (with no fin elements) to escape a $75 \mathrm{~cm}$ diameter plankton net is unlikely to be a major factor influencing capture rates.

Once marine postlarvae have recruited into the Swartvlei estuary, lateral movements would facilitate occupation of shallow nursery grounds where water currents are reduced or absent (Fig. 2). Although postlarvae of certain mugilids and sparids follow this pattern, often forming large shoals in littoral areas, other species adopt a slightly different strategy. Upon entering the estuary using tidal stream transport, nonschooling sole and goby postlarvae soon become part of the demersal fauna where shelter from strong water currents is also available. With increasing size, freedom of movement within the estuary increases, especially when the mouth closes and tidal water currents cease.

Acknowledgements. This project was funded by the SANCOR Estuaries Programme of the CSIR. Much of the work was conducted while at the Institute for Freshwater Studies Swartvlei Laboratory, the use of which is gratefully acknowledged. The co-operation of Dr L. E. Beckley who assisted with fish larval identification and Dr. A. J. Ribbink who commented on a draft of the manuscript is gratefully acknowledged. 


\section{LITERATURE CITED}

Beckley, L. E. (1985). Tidal exchange of ichthyoplankton in the Swartkops estuary mouth, South Africa. S. Afr. J. Zool 20: $15-20$

Blaber, S. J. M., Blaber, T G. (1980). Factors affecting the distribution of juvenile estuarine and inshore fish. J. Fish. Biol. 17: 143-162

Boehlert, G. W., Mundy, B. C. (1987). Recruitment dynamics of metamorphosing English sole, Parophorys vetulus, to Yaquina Bay, Oregon. Estuar. coast. Shelf Sci 25: 261-281

Boehlert, G. W., Mundy, B. C. (1988). Roles of behavioral and physical factors in larval and juvenile fish recruitment to estuarine nursery areas. Am. Fish. Soc. Symp. 3: 51-67

Eldridge, M. B. (1977). Factors influencing distribution of fish eggs and larvae over eight 24-hr samplings in Richardson Bay, California. Calif. Fish Game 63: 101-116

Fore, P. L., Baxter, K. N. (1972). Diel fluctuations in the catch of larval Gulf menhaden, Brevoortia patronus, at Galveston Entrance, Texas. Trans. Am. Fish. Soc. 101: 729-732.

Fortier, L., Leggett, W. C. (1983). Vertical migrations and transport of larval fish in a partially mixed estuary. Can. J. Fish. Aquat. Sci. 40: 1543-1555

Gascuel, D. (1986). Flow-carried and active swimming migration of the glass eel (Anguilla anguilla) in the tidal area of a small estuary on the French Atlantic coast. Helgoländer Meeresunters. 40: 321-326

Henderson, P. A. (1987). The vertical and transverse distribution of larval herring in the River Blackwater estuary, Essex. J. Fish. Biol. 31: 281-290

Huizinga, P. (1987). Hydrodynamic model studies of the Swartvlei estuary. CSIR Report T/SEA 8709, p. 1-23

Kendall, A. W. A.ulstrom, E. H., Moser, H. G. (1984). Early life history stages of fishes and their characters. In: Moser, $\mathrm{H}$. G., Richards, W. G., Cohen, D. M., Fahay, M. P., Kendall, A. W., Richardson, S. L. (eds.) Ontogeny and systematics of fishes. American Society of Ichthyologists and Herpetologists Special Publication No. 1: 11-22

Kluger, J. W. (1975). Hydrographic survey of Sedgefield lagoon. CSIR Report C/SEA 75/13, p. 51

Kok, H. M., Whitfield, A. K. (1986). The influence of open and closed mouth phases on the marine fish fauna of the Swartvlei estuary. S. Afr. J. Zool. 21: 309-315

Lawler, J. P., Weinstein, M. P., Chen, H. Y., Englert, T L. (1988). Modeling of physical and behavioral mechanisms influencing recruitment of spot and Atlantic croaker to the Cape Fear estuary. Am. Fish. Soc. Symp. 3: 115-131

Liptrot, M. R. (1978). Community metabolism and phosphorous dynamics in a seasonally closed South African estuary. M. Sc. thesis, Rhodes University, Grahamstown

Melville-Smith, R. (1978). Aspects of the ecology of fish larvae in the Swartkops estuary, Port Elizabeth. M.Sc. thesis, University of Port Elizabeth

Melville-Smith, R., Baird, D. (1980). Abundance, distribution and species composition of fish larvae in the Swartkops estuary. S. Afr. J. Zool. 15: 72-78

Melville-Smith, R., Baird, D., Wooldridge, T (1981). The utilization of tidal currents by the larvae of an estuarine fish. S. Afr. J. Zool. 16: 10-13

Massmann, W. H., Norcross, J. J., Joseph, E. B. (1963). Distribution of larvae of the naked goby, Gobiosoma bosci, in the York River. Chesapeake Sci. 4: 120-125
Miller, J. M., Reed, J. P., Pietrafesa, L. J. (1984). Patterns mechanism and approaches to the study of migrations of estuarine-dependent fish larvae and juveniles. In: McCleave, J. D., Arnold, G. P., Dodson, J. J., Neill. W H (eds.) Mechanisms of migration in fishes. Plenum Publishing Corp., New York, p. 209-225

Pollock, B. R., Weng, H., Morton, R. M. (1983). The seasonal occurrence of postlarval stages of yellowfin bream, Acanthopagrus australis (Günther), and some factors affecting their movement into an estuary. J. Fish. Biol. 22: 409-415

Roper, D. S. (1986). Occurrence and recruitment of fish larvae in a northern New Zealand estuary. Estuar coast. Shelf Sci. 22: 705-717

Shenker, J. M., Hepner, D. J., Frere, P. E., Currence, L. E. Wakefield, W. W. (1983). Upriver migration and abundance of naked goby (Gobiosoma bosci) larvae in the Patuxent River estuary, Maryland. Estuaries 6: 36-42

Talbot, M. M. J. (1982). Aspects of the ecology and biology of Gilchristella aestuarius ( $\mathrm{G} \& \mathrm{~T}$ ) (Pisces: Clupeidae) in the Swartkops estuary, Port Elizabeth. M. Sc. thesis, University of Port Elizabeth

Wallace, J. H. (1975). The estuarine fishes of the east coast of South Africa. III. Reproduction. Investl Rep. oceanogr. Res. Inst., Durban 41: 1-51

Wallace, J. H., Kok, H. M., Beckley, L. E., Bennett, B., Blaber, S. J. M., Whitfield, A. K. (1984). South African estuaries and their importance to fishes. S. Afr. J. Sci. 80: 203-207

Weinstein, M. P., Weiss, S. L., Hodson, R. G., Gerry, L. R. (1980). Retention of three taxa of postlarval fishes in an intensively flushed tidal estuary, Cape Fear River, North Carolina. Fish. Bull. U. S. 78: 419-435

Whitfield, A. K. (1980). Factors influencing the recruitment of juvenile fishes into the Mhlanga estuary. S. Afr. J. Zool. 15: 166-169

Whitfield, A. K. (1983). Factors influencing the utilization of southern African estuaries by fishes. S. Afr J. Sci. 79: $362-365$

Whitfield, A. K. (1984). The effect of prolonged aquatic macrophyte senescence on the biology of the dominant fish species in a southern African coastal lake. Estuar. coast. Shelf Sci. 18: 315-329

Whitfield, A. K. (1986). Fish community structure response to major habitat changes within the littoral zone of an estuarine coastal lake. Envir. Biol. Fish. 17: 41-51

Whitfield, A. K. (1988a). The role of tides in redistributing macrodetrital aggregates within the Swartvlei estuary. Estuaries 11: 152-159

Whitfield, A. K. (1988b). The Swartvlei estuary fish community and the influence of food availability on resource utilization. Estuaries 11: 160-170

Whitfield, A. K. (1989). Fish larval composition, abundance and seasonality in a southern African estuarine lake. S. Afr. J. Zool. 24: in press

Whitfield, A. K., Allanson, B. R., Heinecken, T J. E. (1983). Swartvlei (CMS 11). In: Heydorn, A. E. F., Grindley, J. R. (eds.) Estuaries of the Cape. Part II. Synopses of available information on individual systems. CSIR Research Report 421, Estuarine and Coastal Research Unit, Stillenbosch, p. $1-62$

Zedler, J. B., Nordby, C. S. (1986). The ecology of Tijuana estuary: an estuarine profile. U.S. Fish Wildl. Serv biol. Rep. 85: 1-104

Manuscript first received: November 15, 1988

Revised version accepted: February 21, 1989

This article was submitted to the editor 